\title{
Treatment -refractory and super refractory schizophrenia - a case study
}

\author{
Schizofrenia lekooporna i super-lekooporna - studium przypadku
Ewelina Soroka ${ }^{1} \mathrm{ABDEF}$, Inga-Ujma Lesiczka ${ }^{1} \mathrm{DE}$, Magdalena $\operatorname{Tracz}^{1}{ }_{\mathrm{BE}}$, Bernarda Bereza ${ }^{2}$, Marcin Olajossy ${ }^{1} \mathrm{AE}$

\author{
${ }^{1}$ II Department of Psychiatry and Psychiatric Rehabilitation, Medical University of Lublin \\ 2 Department of Clinical Psychology, Catholic University of Lublin
}

\begin{abstract}
Refractoriness affects about $25 \%$ of patients treated with antipsychotics, and it is a very big challenge for clinicians. The most commonly accepted definition of refractoriness is: lack of satisfactory clinical response to treatment with at least two antipsychotic drugs, from different groups, carried out at therapeutic doses and for a sufficiently long period.

Aim : The aim of the study is to analyze the case of a patient diagnosed with schizophrenia.

Methods: Analysis of medical records, available literature from recent years on treatment-refractory and super-refractory schizophrenia.

Results: A 53-year-old patient, a bachelor, suffering from paranoid schizophrenia with an extremely severe, non-remission course with drug resistance features. The patient's father and sister also suffer from severe paranoid schizophrenia. The patient became ill at the age of 22. Despite the high doses of clozapine, in a sufficiently long period of time, the patient maintained positive and negative symptoms, cognitive deficits and behavioral disorders.The patient was 14 times psychiatrically hospitalized, twice treated with electroconvulsive therapy, which did not bring results despite the combination of electroconvulsive therapywith psycho pharmacothera py. In addition, the patient was addicted to benzodiazepines, administered during anxiety and anxiety attacks by the mother, during the described hospitalization, gradually discontinued. Patient after several attempts of committing suicide, with a tendency to self-destructive behavior. The illustrated case meets the criteria of super-refractory schizo phrenia (SRS).

Conclusions: 1 . The category of refractory schizophrenia encountered in the literature is not a separate diagnostic category - it does not exist in classification systems, therefore we consider the phenomenon / symptom of drug resistance - variously defined. 2. Social relations have a big impact on the functioning of the patient as well as the course of the disease and prognosis (the role of the family). 3. There are numerous methods for the potentiating of clozapine treatment, of which combining clozapine with EC therapy is effective and safe. The strategy for combining clozapine with EC is effective, but not in all patients.
\end{abstract}

Keywords: schizophrenia, clozapine, treatment refractoriness

\section{Streszczenie}

Wstęp: Lekooporność dotyczy około 25\% pacjentów leczonych przeciwpsychotycznie, stanowiąc bardzo duże wyzwanie dla klinicystów. Najczęściej akceptowana definicja lekooporności to: brak satysfakcjonującej odpowiedzi klinicznej na leczenie co najmniej dwoma lekami przeciwpsychotycznymi, z różnych grup, prowadzone przy zastosowaniu dawek terapeutycznych i przez wystarczająco długi okres.

Cel pracy: Celem niniejszej pracyjestanaliza przypadku pacjenta z rozpoznaniem schizofrenii.

Metody: Analiza dokumentacji medycznej, dostępnego piśmiennictwa ostatnich lat na temat schizofrenii lekoopornej i super-lekoopornej.

Wyniki: Pacjent 53 lata, kawaler, chorujący na schizofrenię paranoidalną o wyjątkowo ciężkim, bezremisyjnym przebiegu z cechami lekooporności. Ojciec i siostra pacjenta również chorują na schizofrenię paranoidalną o ciężkim przebiegu. Pacjent zachorował w wieku 22 lat. Mimo stosowania wysokich dawek klozapiny, w odpowiednio długim okresie czasu, u pacjenta utrzymywały się objawy pozytywne, negatywne, deficyty poznawcze i zaburzenia zachowania. Chory był 14-razy hospitalizowany psychiatrycznie, dwukrotnie leczony terapią elektrowstrząsową, która nie przyniosła efektów mimo połączenia EW z psychofarmakoterapią. Dodatkowo pacjent był uzależniony od benzodiazepin, podawanych w czasie napadów lęku i niepokoju przez matkę, w czasie opisanej hospitalizacji stopniowo odstawianych. Pacjent po kilku próbach samobójczych, z tendencją do zachowań autodestrukcyjnych. Zoobrazowany przypadek spełnia kryteria schizofrenii super-lekoopornej.

Wnioski: 1. Spotykana w piśmiennictwie kategoria schizofrenii lekoopornej nie jest odrębną kategorią diagnostyczną - nie istnieje w systemach klasyfikacyjnych, rozpatrujemy zatem zjawisko/ objaw lekooporności - różnie definiowanej. 2. Relacje społeczne mają duży wpływ na funkcjonowanie pacjenta a także przebieg choroby i rokowania (rola rodziny). 3. Znane są liczne metody potencja lizacji leczenia klozapiną, spośród których skuteczne i bezpieczne wydaje się łączenie klozapiny z EW. Strategia łączenia leczenia klozapiną z EW jest skuteczna, lecz nie u wszystkich pacjentów.

Słowa kluczowe: schizofrenia, klozapina, lekooporność

\section{Introduction}

(C) 2017 Medical University of Lublin. This is an open access article distributed under the Creative Commons Attribution-NonComercial-No Derivs licence (http://creativecommons.org/licenses/by-nc-nd/3.0/) 
The phenomenon of refractoriness (also symptom) consisting in the lack of positive effects of treatment despite the use of the appropriate drug, at the right dose and for a sufficiently long time [1]. The concept of refractoriness is very broad and variously defined, often abused [1,2].

Criteria for the diagnosis of treatment-refractory schizophrenia are not included in any of the most recent classifications used, e.g. in ICD-10 or DSM-5 [3]. According to Kane, treatment-refractory schizophrenia is the lack of response to treatment, in the last five years, to at least the third treatment with neuroleptic drugs (of at least two chemical classes) in doses equivalent to 400-600 mg chlorpromazine, for a period of (each therapy) at least 6 weeks, without significant remission of symptoms, in the absence of a period of good functioning during these five years.According to Suzuki et al.,refractoriness to treatment in schizophrenia is a documented lack of clear improvement after at least two treatments with antipsychotic drugs, after at least 6 weeks each [2]. The most commonly accepted definition of refractoriness is lack of satisfactory clinical response to treatment with at least two antipsychotic drugs, from different groups, carried out at therapeutic doses and for a sufficiently long period [1]. Jarema specifies this definition - "satisfactory" improvement is the one that concerns both the symptoms and the patient's functioning as well as the subjectively assessed improvement of well-being [1]. It is about the multidimensional improvement and assessment of the patient's condition in the area of positive symptoms, negative symptoms, affective symptoms, cognitive deficits, behavioral disorders, personal, social and professional functioning as well as the frequency and duration of hospitalization [4].By "at least two groups of drugs" are meant drugs derived from two chemically or pharmacologically differing groups: in practice, this usually means classical drugs and atypical drugs, such a difference may concern various chemical groups, e.g. derivatives of phenothiazine and butyrophenone. Clozapine is not required to be one of these drugs.The term "therapeutic doses" is understood as the usual doses of the drug recommended in the description of the medicinal product. In some cases, the socalled chlorpromazine equivalent is used to assess the dose of antipsychotics, but it should not be lower than $400 \mathrm{mg}$ of chlorpromazine per day, so that the dose of antipsychotics is considered adequate [4].A sufficiently long treatment period is understood as the time required for the drug to act, usually it cannot be less than two weeks (unless bad tolerance and / or complications prevent the continuation of treatment) and usually not longer than 8 weeks, although the time limit of the maximum time to wait for improvement is not necessary; it is mainly about a few days of treatment, which cannot be considered long enough. The pseudo-refractoriness is a condi- tion in which the above definition has not been met, because the treatment was not conducted according to the listed criteria, or despite meeting these criteria, the patient did not take medications.Because not all researchers apply the same refractoriness criteria, it is difficult to determine the prevalence of this phenomenon. It can be assumed with high probability that it concerns up to $1 / 4$ of patients treated with antipsychotics [1]. In patients suspected of treatment-refractoriness, the following should first be verified before further pharmacotherapy is undertaken: verify the diagnosis, excluding administration of psychoactive substances and organic damage to the central nervous system, assess the cooperation of the patient in treatment, assess the effect of comorbidity of other mental disorders and somatic diseases, assess other factors that may affect the effects of treatment (e.g. nutritional status), if possible, check the concentration of the drug in the serum, assess the impact of interaction, determine the possible occurrence of stressful situations [4].After excluding all other causes than refractoriness of the lack of positive effects of treatment, one of these strategies should be adopted: administration of clozapine, of two antipsychotics or the potentiation of antipsychotic treatment by adding a mood stabilizer (valproic acid derivatives, carbamazepine, lithium salts) or other substances, e.g. glycine [1].Potentiation of antipsychotic medication with antidepressants is usually ineffective, except when the depressive symptoms dominate in the clinical picture. Similarly, attempts to potentiate with procognitive drugs, e.g. donepezil [1.4], are ineffective. The effectiveness of clozapine in patients with schizophrenia, in which at least two treatments with other antipsychotics did not provide a satisfactory therapeutic response is estimated at 37-68\% [5].Grochowski raises the problem of clozapine-refractory treatment.In cases of clozapinetreatment failure, clinicians are very often forced to use different types of therapeutic innovations, first of all optimizing the treatment and when it is ineffective attempts to potentiate the therapeutic effect of clozapine, by the simultaneous use of another antipsychotic, a mood stabilizer, a benzodiazepine, an antidepressant, an NMDA agonist or finally electroconvulsive therapy.There seems to be no evidence of the advantage of one strategy to enhance the therapeutic effect of clozapine over others $[6,13]$. Sobów, in turn, draws attention to the awareness of the risks and benefits associated with the use of clozapine as a prerequisite for the effective and safe use and full use of the remarkable properties of this drug. The reason for the relatively rare use of clozapine is the opinion of the drug as having serious adverse events (agranulocytosis and other blood dyscrasias, cardiomyopathy, myocarditis, intestinal obstruction, convulsions), these complications 
can be prevented and treated, provided that full diagnostic vigilance is maintained [6].

Aamani, Kandra et al. determined the efficacy of clozapine in treatment-refractory schizophrenia (TRS) by conducting a short-term prospective study among patients hospitalized at the Psychiatric Department of AllaliSita Rama Raju Academy of Medical Sciences for 8 weeks. This study proved that clozapine is a beneficial and relatively well tolerated drug in TRS [7].

Super-refractory schizophrenia (SRS) is a schizophrenia that meets the criteria of refracroriness and, in addition, no response to at least 6-month clozapine therapy (300$900 \mathrm{mg} / \mathrm{p}$.). Approximately $30 \%$ of patients with therapyresistant schizophrenia also meet the SRS criteria [8].

\section{There are various strategies for augmentation in patients suffering from schizophrenia}

with an inadequate response to clozapine. Sommer et al. evaluated the effect of using various substances in augmentation in the treatment of schizophrenia and schizoaffective disorder. The change in score in the PANSS or BPRS scale was assessed, body weight, BMI, PRL concentration in the blood between the augmented group and the placebo group, were monitored. A study by Sommer et al. have showed that there is not enough evidence for lamotrigine and topiramate to treat these substances as sufficiently effective augmentation strategies in patients resistant to clozapine [9]. Small et al. compared the addition of lithium carbonate to clozapine with the addition of placebo in a double-blind trial and observed improvement in the group with the addition of lithium only to patients with schizoaffective disorder and not with schizophrenia.On the other hand, augmentation with antidepressants was ineffective except for citalopram (improvement of negative symptoms), a similar effect was not observed for fluoxetine and mirtazapine. Whag et al. reviewed three studies on augmentation of clozapine with sulpiride and indicated a slight advantage of sulpiride over placebo. Barbui et al. also analyzed the addition of an antipsychotic drug to clozapine and also included open-label studies, pointing to the low effectiveness of such augmentation [9].Also, the addition of risperidone to clozapine in patients not responding or partially responding to treatment cannot be recommended as a standard treatment method [10]. The bestdocumented efficacy of randomized trials using placebo are those with addinglamotrigine to ineffectiveclozapinetherapy. The results of research with the use of risperidone are ambiguous [5].

When drug therapy fails or when its management is not possible as a method of choice, electroconvulsive therapy (ECT) is recommended [4]. The profile of side effects of combination therapy (antipsychotics + ECT) is not different from the EC treatments, it is safe and well tolerated [16]. ECT can be combined with clozapine treatment and the positive effects of this strategy were observed in approximately $40 \%$ of patients treated with clozapine in combination with ECT [4].Augmentation of clozapine therapy with ECT in the treatment of clozapinerefractory schizophrenia is a safe and effective method of treatment. The study of Petrides et al. showed a $50 \%$ clinical response with strict criteria of $40 \%$ reduction of symptoms. This is the highest efficacy reported in the study of augmentation of clozapine treatment. However, further research is required to determine the effectiveness of treatment and the need for maintenance treatment [11].

Regarding repetitive transcranial magnetic stimulation (rTMS) - there is no data to recommend this technique in refractory and super-refractory patients [4].

\section{Case study}

A 53-year-old man, a bachelor, unemployed, pensioner, lives with a generational family. The patient's sister and father have been treated for paranoid schizophrenia. The patient has been treated for many years because of paranoid refractory schizophrenia. The patient began to show mental disorders at 22 years of age. Since then, he has been 14 times psychiatrically hospitalized with F20 diagnosis. The patient repeatedly attempted suicide, showed a tendency to self-harm. The course of the patient's disease was severe, with no remission, the patient had drug resistance, and two series of electroconvulsive therapy were ineffective.In the patient's home there was a very difficult living environment and also emotional climate between the family members, very strongly connected to one another (the illness of the sister and the patient - very severe). During thepersisting illness, the patient reported on outpatient appointments and used the recommended medications. Communityactivities (community nurse, social skills trainings) have been attempted several times.The patient did not follow the recommendations resulting from these activities, he did not agree to participate in classes in the communitynursing home. According to the medical staff - the patient's mother also did not see the purpose in undertaking such activities. With regard to the recent hospitalization - the patient's mental state was not good for a long time - hospitalization was dictated to him by the necessity of withdrawal of diazepam, a drug that he was using almost every day because of the anxiety and fear.The patient showed selfdestructive behaviors (he banged his head against the wall), revealed suicidal thoughts. The patient reported the occurrence of intrusive thoughts (about guilt, punishment, wrongdoing), auditory hallucinations about the insulting content to the patient, articulated delusional and depressive delusions (delusions of guilt and punishment - "I killed the ward nurse, I killed the doctor, I will go to 
hell").The patient also confirmed experiencing visual hallucinations. The psychotic experiences of the patient had a strong religious background. He felt the need to touch other people, he made with his arm the sign of the cross. In the past, he showed exhibitionist behavior. In the past history - 5 suicide attempts (jumping from the balcony, jumping in front of a car). At the admission room, the contact with the patient was difficult, mumble speech due to neuroleptic saturation, and chaotic statements.The patient showed production symptoms (auditory hallucinations, paranoid delusions, depressive content), anxiety and fear. The patient was in bad hygienic condition, with yellowish color of the patient's skin. The patient exhibited emotional blunting, bizarre "symbolic" behaviors (signs by hand in the air) - a kind of ritual. He was autistic. A diagnosis was made - a paranoid refractory schizophrenia with features of chronicity F20.0, addiction to benzodiazepines.During the hospitalization of the patient, the psychotic symptoms described above did not subside, only a slight reduction in their severity occurred.

During the hospital treatment, the patient was mechanically immobilized with safety belts, more often at the beginning of psychiatric hospitalization (with symptoms of psychomotor agitation, persecutory perception, imperative hallucinations, persistent obsessive thoughts about his "offenses and sins").With continued treatment, the patient was observed in a better mental state, playing chess, more willing to answer questions, willingly and more than usually, helpful towards other patients. He was discharged from the hospital after a long period of abstinence from sedatives (benzodiazepines), with a slight periodically visible improvement of the mental state (socalled "better days"). Hospitalization lasted just over 3 months. The treatment included: clozapol in a maximum dose of $400 \mathrm{mg} / \mathrm{d}$, levomepromazine in a maximum dose of $125 \mathrm{mg} / \mathrm{d}$, hydroxyzine in a dose of max. $125 \mathrm{mg} / \mathrm{d}$, Fluanxoldepot at a dose of max. $40 \mathrm{mg} / \mathrm{ml}$ (2 amp.).The above-mentioned drugs were taken by the patient throughout the entire period of hospitalization. For the first two weeks, he also received haloperidol at a dose of max. $5 \mathrm{mg} / \mathrm{d}$ and gradually discontinued Cloranxen - at a dose of max. $30 \mathrm{mg} / \mathrm{d}$. It was recommended to take clozapine in a dose of $100 \mathrm{mg} 1+1+3$, Tisercin in a dose of 25 $\mathrm{mg} 1+1+4$, Propranolol 30mg/d and hydroxyzine 175 $\mathrm{mg} / \mathrm{d}$ and regular injection of Fluanxol depot $20 \mathrm{mg} / \mathrm{ml}$ amp. every 10 days.

\section{Discussion}

The patient was repeatedly hospitalized in a psychiatric ward, it was a long hospitalization lasting several months. The Polish standards of schizophrenia treatment were followed [4].

Because there was no response to other antipsychotics, clozapine was included in the treatment. Psy- choactive substances and organic CNS damage were excluded, as well as the lack of cooperation in taking drugs. The patient was taking medication. The coexistence of benzodiazepines dependence was confirmed, the state of nutrition, circulatory and respiratory capacity were assessed, and other factors that may influence the effects of treatment were evaluated. The patient was diagnosed with refractoriness to treatment according to Jarema's definition [1].Clozapine plays a big role in the treatment of treatment-refractory patients. This patient was treated for many years with clozapine in high doses and yet the symptoms of the disease persisted. According to the criteria above, this is a case of super-refractory schizophrenia (SRS).

In addition, in our patient a series of electroconvulsive procedures were used twice. Due to the serious condition of the patient, the treatments were a therapeutic strategy parallel to psychopharmacotherapy. Despite reports of their greatest efficacy in the augmentation of clozapine treatment $[11,17,18]$, the electroconvulsive therapy in this patient did not produce results. Negative and positive symptoms as well as cognitive deficits and behavioral disorders continued.Raffard et al. in the pilot study evaluated cognitive insight in patients suffering from schizophrenia and in their biological parents. It has been proven that a better insight into the disease symptoms of offspring is associated with a cognitive insight in the biological parents of patients suffering from schizophrenia [19].In the present case, the patient's mother was an elderly person with non-correctible beliefs, she placed great emphasis on somatic matters of family members, and less attention was focused on conflicts in the psychological sphere.

Also the environmental activity attempts failed.

Asarnow et al. put forward the hypothesis of the etiological continuation, relationship between COS (childhoodonsetschizophrenia) and AOS (adult-onset schizophrenia) [20]. The patient's father suffered from paranoid schizophrenia, was helpless and played a marginal role in the family,the mother probably did not provide emotional stability, warmth, she was overprotective and perhaps contributed to the deficit of our patient's social interactions.

\section{Conclusions}

1. The category of treatment-refractory schizophrenia encountered in the literature is not a separate diagnostic category - it does not exist in classification systems, so we consider the phenomenon / symptom of treatmentrefractorinessfrom variously defined perspective.

2. Social relations have a great impact on the functioning of the patient as well as the course of the disease and prognosis (the role of the family).

3. There are numerous methods for the potentiation of clozapine treatment, of which combining clozapine with ECT is effective and safe. The strategy for combining clozapine with ECT is effective, but not in all patients. 


\section{Wstęp}

Lekooporność zjawisko (także objaw) polegające na braku korzystnych efektów leczenia mimo stosowania odpowiedniego leku, w odpowiedniej dawce i przez odpowiednio długi czas [1]. Pojęcie lekooporności jest bardzo szerokie i różnorako definiowane, często nadużywane [1,2].

Kryteria rozpoznania schizofrenii opornej na leczenie nie są ujęte $\mathrm{w}$ żadnej $\mathrm{z}$ najnowszych stosowanych klasyfikacji np. w ICD-10 lub DSM-5 [3]. Wg Kane'a schizofrenia lekooporna to brak odpowiedzi na leczenie, w ciągu ostatnich pięciu lat,na co najmniej trzecią terapię lekami neuroleptycznymi (co najmniej z dwóch klas chemicznych) w dawkach równoważnych 400-600 mg chloropromazyny,przez okres (każda terapia) co najmniej 6 tygodni, bez znaczącego ustąpienia objawów, przy braku okresu dobrego funkcjonowania w ciągu tychże pięciu lat. Wg Suzuki i wsp. lekooporność w schizofrenii to udokumentowany brak wyraźnej poprawy po co najmniej dwóch kuracjach lekami antypsychotycznymi, po co najmniej 6 tygodni każda [2]. Najczęściej akceptowana definicja lekooporności to: brak satysfakcjonującej odpowiedzi klinicznej na leczenie co najmniej dwoma lekami przeciwpsychotycznymi, z różnych grup, prowadzone przy zastosowaniu dawek terapeutycznych i przez wystarczająco długi okres [1]. Jarema uściśla ową definicję - "satysfakcjonująca" poprawa to taka, która dotyczy zarówno objawów, jak i funkcjonowania chorego oraz subiektywnie ocenianej poprawy samopoczucia [1]. Chodzi zatem o poprawę wielowymiarową i ocenę stanu chorego w zakresie objawów pozytywnych, objawów negatywnych, objawów afektywnych, deficytów poznawczych, zaburzeń zachowania, funkcjonowania osobistego, społecznego i zawodowego oraz częstości i czasu trwania hospitalizacji [4]. Przez "co najmniej dwie grupy leków" należy rozumieć leki pochodzące z dwóch różniących się chemicznie lub farmakologicznie grup: w praktyce oznacza to najczęściej leki klasyczne i leki atypowe, taka różnica może dotyczyć różnych grup chemicznych, np. pochodnych fenotiazyny i butyrofenonu. Nie jest wymogiem aby jednym z tych leków była klozapina. Przez "dawki terapeutyczne" rozumie się zwykle stosowane dawki leku zalecane w opisie produktu leczniczego; Niekiedy do oceny wysokości dawki LPP bywa stosowany tak zwany ekwiwalent chloropromazyny, przy czym uważa się, że nie powinien być on niższy niż 400 mg chloropromazyny dziennie, aby dawkę LPP uznać za odpowiednią [4]. Przez wystarczająco długi okres leczenia rozumie się okres potrzebny do zadziałania leku, zwykle nie może to być krócej niż dwa tygodnie (chyba, że zła tolerancja i /lub powikłania uniemożliwiają kontynuację leczenia) i z reguły nie dłużej niż 8 tygodni, chociaż ograniczenie czasowe maksymalnego czasu trwania oczekiwania na uzyskanie poprawy nie jest niezbędne; chodzi przede wszystkim o kilkudniowe okresy leczenia, które nie mogą być uznane za wystarczająco długie. Lekooporność rzekoma to stan, w którym powyższa definicja nie została spełniona, gdyż leczenie nie było prowadzone według wymienionych kryteriów, albo mimo spełnienia tych kryteriów chory nie przyjmował leków. Ponieważ nie wszyscy badacze stosują jednakowe kryteria lekooporności trudno jest ustalić rozpowszechnienie tego zjawiska. Można z dużym prawdopodobieństwem przyjąć, że dotyczy ono do $1 / 4$ chorych leczonych przeciwpsychotycznie [1]. U chorych, u których podejrzewa się lekooporność, przed podjęciem dalszej farmakoterapii w pierwszej kolejności należy: zweryfikować rozpoznanie wykluczając przyjmowanie substancji psychoaktywnych i organiczne uszkodzenie ośrodkowego układu nerwowego, ocenić współpracę chorego w leczeniu, ocenić wpływ współwystępowania innych zaburzeń psychicznych i chorób somatycznych, ocenić inne czynniki mogące mieć wpływ na efekty leczenia (np. stan odżywienia), o ile to możliwe sprawdzić stężenie leku w surowicy, ocenić wpływ interakcji, ustalić ewentualne występowanie sytuacji stresowych [4]. Po wykluczeniu wszelkich innych niż lekooporność przyczyn braku korzystnych efektów leczenia, należy przyjąć jedną ze strategii tj. zastosowanie klozapiny, zastosowanie dwóch leków przeciwpsychotycznych albo potencjalizacja leczenia lekiem przeciwpsychotycznym poprzez dodanie leku normotymicznego (pochodnych kwasu walproinowego, karbamazepiny, soli litu) czy innych substancji np. glicyny [1]. Potencjalizacja leczenia przeciwpsychotycznego lekami przeciwdepresyjnymi zwykle jest nieskuteczna, poza stanami gdy w obrazie klinicznym dominują objawy depresyjne. Podobnie nieskuteczne są próby potencjalizacji lekami prokognitywnymi np. donepezilem [1,4]. Skuteczność klozapiny u chorych na schizofrenię, u których co najmniej dwie kuracje innymi lekami przeciwpsychotycznymi nie spowodowały zadowalającej odpowiedzi terapeutycznej ocenia się na 37-68\%[5]. Grochowski porusza problem oporności na leczenie klozapiną. W przypadkach niepowodzenia leczenia klozapiną, klinicyści bardzo często zmuszeni są do stosowania różnego rodzaju innowacji terapeutycznych, w pierwszej kolejności optymalizacji leczenia a gdy ta jest nieskuteczna prób potencjalizacji efektu terapeutycznego klozapiny, przez jednoczesne zastosowanie innego LPP, leku normotymicznego, benzodiazepiny, leku przeciwdepresyjnego, agonisty NMDA czy wreszcie terapii elektrowstrząsowej. Wydaje się, że brakuje dowodów na przewagę jednej strategii wzmacniania efektu terapeutycznego klozapiny nad innymi [6,13]. Sobów z kolei zwraca uwagę na świadomość ryzyka i korzyści związanych ze stosowaniem klozapiny jako warunku koniecznego by skutecznie oraz bezpiecznie i w pełni wykorzystywać niezwykłe właściwości tego leku. Powodem relatywnie rzadkiego sięgania po klozapinę jest postrzeganie leku jako obarczonego poważnymi 
objawami niepożądanymi (agranulocytoza i inne dyskrazje krwi, kardiomiopatia, zapalenie mięśnia sercowego, niedrożność jelit, drgawki), powikłaniom tym można zapobiegać i leczyć, pod warunkiem zachowania pełnej czujności diagnostycznej[6].

Aamani, Kandra i wsp. określali skuteczność klozapiny w lekoopornej schizofrenii, prowadząc krótkoterminowe badanie prospektywne wśród pacjentów hospitalizowanych w Oddziale Psychiatrycznym w Alluri Sita Rama Raju Academy of MedicalSciences przez okres 8 tyg. Badanie to dowiodło, że klozapina jest korzystnym i względnie dobrze tolerowanym lekiem w TRS [7].

Super-lekooporna schizofrenia (SRS) to schizofrenia spełniająca kryteria lekooporności i dodatkowo brak odpowiedzi na co najmniej 6-miesięczną terapię klozapiną (300-900mg/p.d.) Około 30\% pacjentów ze schizofrenią lekooporną spełnia także kryteria SRS [8].

Znane są różne strategie augmentacji u pacjentów chorujących na schizofrenię z niewystarczającą odpowiedzią na klozapinę. Sommer i wsp. ocenili wielkość efektu stosowania różnych substancji w augmentacji w przebiegu leczenia schizofrenii i zaburzenia schizoafektywnego. Oceniano zmianę w punktacji w skali PANSS lub w skali BPRS, monitorowano masę ciała, BMI, stężenie PRL we krwi pomiędzy grupą poddawaną augmentacji i grupą placebo. Badanie Sommer i wsp. dowiodło, że dla lamotryginy i dla topiramatu nie ma wystarczających dowodów na to, aby traktować te substancje za wystarczająco skuteczne strategie augmentacji u pacjentów opornych na klozapinę [9]. Small i wsp. porównywali dodanie węglanu litu do klozapiny z dodaniem placebo w podwójnie ślepej próbie i obserwowali poprawę $\mathrm{w}$ grupie $\mathrm{z}$ dodaniem litu jedynie $\mathrm{w}$ odniesieniu do pacjentów z zaburzeniem schizoafektywnym, a nie ze schizofrenią. Z kolei augmentacja lekami przeciwdepresyjnymi była nieskuteczna z wyjątkiem citalopramu (poprawa odnośnie objawów negatywnych), podobny efekt nie występował dla fluoksetyny i mirtazapiny. Wnag i wsp. dokonali przeglądu 3 badań dotyczących augmentacji klozapinysulpirydem i wskazywali na niewielką przewagę sulpirydu nad placebo. Barbui i wsp. również analizowali dodanie leku antypsychotycznego do klozapiny i włączyli również badania otwarte, wskazywali na niewielką skuteczność takiej augmentacji [9]. Również dodanie risperidonu do klozapiny u pacjentów nieodpowiadających lub odpowiadających częściowo na leczenie nie może być nie może być zalecane jako standardowa metoda lecznicza[10]. Najlepiej udokumentowanymi pod względem skuteczności badaniami randomizowanymi z użyciem placebo są polegające na dodaniu do nieefektywnej terapii klozapiną lamotryginy. Wyniki badań $\mathrm{z}$ użyciem risperidonu są niejednoznaczne[5].

Gdy farmakoterapia zawodzi lub gdy jej prowadzenie nie jest możliwe jako metodę $\mathrm{z}$ wyboru zaleca się zabiegi elektrowstrząsowe[4].Profil objawów ubocznych terapii skojarzonej ( $\mathrm{LPP}+\mathrm{EW}$ ) nie różni się od samych zabiegów EW, jest ona bezpieczna i dobrze tolerowana [16]. Terapię EW można łączyć z leczeniem klozapiną a pozytywne efekty tej strategii obserwowano u około $40 \%$ pacjentów leczonych klozapiną w połączeniu z EW [4]. Augmentacja terapii klozapiną przy pomocy ECT w leczeniu klozapinoopornej schizofrenii jest bezpieczną i efektywną metodą leczenia. Badanie Petrides i wsp. wykazało 50\% odpowiedź kliniczną przy rygorystycznych kryteriach 40\% redukcji objawów. Jest to najwyższa znana autorom tego badania skuteczność podawana w próbach augmentacji leczenia klozapiną. Wymagane są jednak kolejne badania nad tym zagadnieniem celem ustalenia skuteczności leczenia i konieczności stosowania leczenia podtrzymującego [11]

W odniesieniu do powtarzalnej przezczaszkowej stymulacji magnetycznej (rTMS) - nie ma danych pozwalających na rekomendowanie tej techniki u chorych lekoopornych i superlekoopornych [4].

\section{Opis przypadku}

Pacjent lat 53, kawaler, bezrobotny, rencista, mies zka $\mathrm{z}$ rodziną generacyjną. Siostra chorego $\mathrm{l}$ oraz ojciec leczyli się z powodu schizofrenii paranoidalnej. Pacjent od wielu lat leczony z powodu lekoopornej schizofrenii paranoidalnej. Badany zaczął zdradzać zaburzenia psychiczne w 22 roku życia. Od tego czasu 14 razy hospitalizowany psychiatrycznie z rozp. F20. Chory kilkukrotnie podejmował próby samobójcze, wykazywał tendencje do samookaleczeń. Przebieg choroby pacjenta był ciężki, bezremisyjny, u chorego występowała lekooporność, nieskuteczne były również dwie serie ordynowanych zabiegów elektrowstrząsowych. W domu chorego panowała bardzo trudna atmosfera życiowa i takiż klimat emocjonalny między członkami rodziny, bardzo silnie ze sobą związanymi (chorowanie siostry i samego pacjenta bardzo ciężkie). W czasie długo trwającej choroby pacjent zgłaszał się na wizyty ambulatoryjne, stosował zalecane leki. Kilkakrotnie podejmowano próby oddziaływań środowiskowych (pielęgniarka środowiskowa, treningi umiejętności społecznych). Pacjent nie realizował zaleceń wynikających z tych oddziaływań, nie wyrażał zgody na udział w zajęciach w środowiskowym domu pomocy. Wg relacji personelu medycznego - matka pacjenta również nie widziała celu w podejmowaniu tego typu działań. W kontekście ostatniej hospitalizacji - stan psychiczny pacjenta nie był dobry od dłuższego czasu - hospitalizacja ta podyktowana była koniecznością odstawienia mu diazepamu, który to lek chory przyjmował prawie codziennie z powodu niepokoju i lęku. Pacjent wykazywał zachowania autodestrukcyjne (uderzał głową w ścianę), ujawniał myśli samobójcze. Pacjent zgłaszał występowanie myśli natrętnych (o winie, karze, popełnionych złych czynach), 
halucynacji słuchowych o obraźliwej dla chorego imperatywnej treści, wypowiadał urojenia prześladowcze oraz depresyjne (urojenia winy i kary - „zabiłem salowego, zabiłem panią doktor, pójdę do piekła”). Pacjent potwierdzał także doświadczanie omamów wzrokowych. Przeżycia psychotyczne pacjenta miały silne podłoże religijne. Chory czuł potrzebę dotykania innych ludzi, kreślił dłonią znak krzyża. W przeszłości wykazywał zachowania ekshibicjonistyczne. W wywiadzie - 5 prób samobójczych (skok z balkonu, rzucanie się pod samochód). W izbie przyjęć Kliniki kontakt $\mathrm{z}$ pacjentem był trudny, mowa bełkotliwa $\mathrm{z}$ powodu wysycenia neuroleptycznego, a wypowiedzi chaotyczne. Chory ujawniał objawy wytwórcze (halucynacje słuchowe, urojenia paranoidalne, o treści depresyjnej), niepokój i lęk. Był zaniedbany higienicznie, zwracało uwagę zażółcenie powłok ciała pacjenta. Chory wykazywał stępienie emocjonalne, dziwaczne „symboliczne” zachowania (znaki dłonią w powietrzu) swego rodzaju rytuały. Był autystyczny. Postawiono rozpoznanie - schizofrenia paranoidalna lekooporna o cechach przewlekłości F20.0, uzależnienie od benzodiazepin. W trakcie hospitalizacji nie uzyskano u pacjenta ustąpienia objawów psychotycznych, opisanych powyżej, jedynie niewielkie zmniejszenie ich nasilenia. W czasie leczenia szpitalnego pacjent był wielokrotnie unieruchamiany mechanicznie pasami bezpieczeństwa, częściej na początku hospitalizacji psychiatrycznej (z objawami pobudzenia psychoruchowego, urojeń prześladowczych, omamów imperatywnych, uporczywych myśli natrętnych na temat swoich „przewinień i grzechów"). W miarę trwania hospitalizacji obserwowano pacjenta $\mathrm{w}$ lepszym staniepsychicznym, grającego w szachy, chętniej odpowiadającego na pytania, mówiącego chętnie i więcej niż zazwyczaj, uczynnego wobec innych pacjentów. Wypisany po dłuższym okresie abstynencji od środków uspokajających (benzodiazepiny), z niewielką okresowo widoczną, poprawą stanu psychicznego (tzw. „lepsze dni"). Hospitalizacja trwała nieco ponad 3 miesiące. Zastosowane leczenie: klozapol w dawce maksymalnej $400 \mathrm{mg} / \mathrm{d}$, lewomepromazyna w dawce maksymalnej $125 \mathrm{mg} / \mathrm{d}$, hydroksyzyna w dawce max. $125 \mathrm{mg} / \mathrm{d}$, Fluanxol depot w dawce max. $40 \mathrm{mg} / \mathrm{ml}$ ( 2 amp.). Powyższe leki pacjent przyjmował przez cały okres hospitalizacji. Przez pierwsze dwa tygodnie otrzymywał także haloperidol w dawce max. $5 \mathrm{mg} / \mathrm{d}$ oraz stopniowo odstawiany Cloranxen - $\mathrm{w}$ dawce max. 30 $\mathrm{mg} / \mathrm{d}$. Zalecono przyjmowanie klozapiny $\mathrm{w}$ dawce $100 \mathrm{mg}$ $1+1+3$, Tisercinu $\mathrm{w}$ dawce $25 \mathrm{mg} 1+1+4$, Propranololu $30 \mathrm{mg} / \mathrm{d}$ i hydroxyzyny $175 \mathrm{mg} / \mathrm{d}$ oraz regularne wykonywanie iniekcji Fluanxolu depot $20 \mathrm{mg} / \mathrm{ml}$ amp. co $10 \mathrm{dni}$.

\section{Omówienie}

Pacjent był wielokrotnie hospitalizowany psychiatrycznie, były to długie, kilkumiesięczne hospitalizacje.
Postępowano zgodnie z polskimi standardami leczenia schizofrenii. [4].

Wobec braku odpowiedzi na inne leki przeciwpsychotyczne włączono u pacjenta klozapinę. Wykluczono przyjmowanie substancji psychoaktywnych oraz organiczne uszkodzenie OUN oraz brak współpracy w zakresie przyjmowania leków. Chory leki przyjmował. Rozpoznanowspółwystępowanie uzależnienia od benzodiazepin, oceniono stan odżywienia, wydolność krążeniową i oddechową, oceniano przy tym inne czynniki mogące mieć wpływ na efekty leczenia. Stwierdzono u pacjenta lekooporność, wg definicji Jaremy [1].Klozapina odgrywa dużą rolę w leczeniu chorych lekoopornych. Omawiany pacjent leczony był przez wiele lat klozapiną w wysokich dawkach a mimo to objawy choroby utrzymywały się. Zgodnie z kryteriami powyżej, jest to przypadek schizofrenii super-lekoopornej.

Dodatkowo u naszego pacjenta stosowano dwukrotnie serię zabiegów elektrowstrząsowych. Z uwagi na poważny stan pacjenta zabiegi stanowiły równoległą do psychofarmakoterapii strategię leczniczą. Pomimo doniesień na temat ich największej skuteczności jeśli chodzi o augmentację leczenia klozapiną $[11,17,18]$, u omawianego pacjenta zabiegi elektrowstrząsowenie przyniosły rezultatów. W dalszym ciągu utrzymywały się objawy negatywne i pozytywne a także deficyty poznawcze i zaburzenia zachowania. Raffard i wsp. w badaniu pilotażowym oceniali wgląd poznawczy u pacjentów cierpiących na schizofrenię i uich biologicznych rodziców. Zostało dowiedzione, że lepszy wgląd w symptomy chorobowe potomstwa jest związany z wglądem poznawczym u biologicznych rodziców pacjentów cierpiących na schizofrenię [19]. W omawianym przypadku mama pacjenta była osobą starszą o niekorygowalnych przekonaniach, kładła duży nacisk na sprawy somatyczne członków rodziny, mniej uwagi skupiano na konfliktach sfery psychologicznej.

Także próby oddziaływań środowiskowych zakończyły się niepowodzeniem.

Asarnow i wsp., stawiają hipotezę etiologicznych kontynuacji, łączności pomiędzy COS (childhoodonsetschizophrenia) i AOS (adult-onset schizofrenia)[20]. Ojciec pacjenta chorował na schizofrenię paranoidalną, był bezradny i pełnił w rodzinie marginesową rolę, matka zaś prawdopodobnie nie dostarczała stabilizacji emocjonalnej, ciepła, była nadopiekuńcza i być może przyczyniła się do deficytu interakcji społecznych naszego pacjenta.

\section{Wnioski}

1. Spotykana w piśmiennictwie kategoria schizofrenii lekoopornej nie jest odrębną kategorią diagnostyczną nie istnieje w systemach klasyfikacyjnych, rozpatrujemy zatem zjawisko/ objaw lekooporności - różnie definiowanej. 
2. Relacje społeczne mają duży wpływ na funkcjonowanie pacjenta a także przebieg choroby i rokowania ( rola rodziny).

3. Znane są liczne metody potencjalizacji leczenia klozapiną, spośród których skuteczne i bezpieczne wydaje się łączenie klozapiny z EW. Strategia łączenia leczenia klozapiną z EW jest skuteczna, lecz nie u wszystkich pacjentów.

\section{Conflict of interest}

The authors have declared no conflict of interest.

\section{References:}

1. Jarema M. Leksykon schizofrenii. Poznań; Termedia 2010.

2. Brykalski J., Rajewska-Rager A., Sprawozdanie z IV Szkoły Neuropsychofarmakologii (ECNP), Oxford 2012.

3. Weiden P. J. How manytreatmentsbeforeclozapine? medicationchoicesacross the spectrum of treatmentresistance in schizophrenia. The Journal of clinical psychiatry, 2016, 77(5), e594.

4. Jarema M. Standardy leczenia farmakologicznego niektórych zaburzeń psychicznych, wyd. II, Gdańsk; Via Medica 2015.

5. Jaracz J. Dodanie leku przeciwpsychotycznego II generacji lub leku przeciwpadaczkowego jako metoda postępowania u chorych na schizofrenię ze słabą odpowiedzią na klozapinę.

6. Sobów T. Klozapina: między skutecznością a bezpieczeństwem. Psychiatria i Psychologia Kliniczna, 2015, 15.2: 57-60.

7. Aamani M., Kalyan K., Somasundara B. "A Study on Efficacy of CLOZAPINE in TreatmentResistantSchizophrenia." International Journal of ScientificResearch, 2016, 4.6.

8. Meder J., Tyszkowska M., Jarema M., Araszkiewicz A., Szafrański T. Leki przeciwpsychotyczne w praktyce lekarza psychiatry. Leczenie pacjentów z rozpoznaniem schizofrenii lekoopornej. Psychiatr Pol, 2008, 6, 859-873.

9. Sommer I.E., Begemann M.J., Temmerman A., Leucht S. Pharmacologica laugmentation strategies for schizophrenia patients with insufficient response to clozapine: a quantitativeliteraturereview. Schizophreniabulletin, 2012, 38(5), 1003-1011.

10. Sobów T., Magierski R., Kłoszewska I. Risperidon jako terapia dodana do klozapiny w schizofrenii opornej na leczenie: metaanaliza randomizowanych badań kontrolowanych przy zastosowaniu placebo, 2009.

11. Petrides G., Malur C., Braga R.J., Bailine S.H., Schooler N.R., Malhotra A.K. et al. Electroconvulsive therapy augmentation in clozapine-resistant schizophrenia: a prospective, randomizedstudy. American Journal of Psychiatry, 2014, 172(1), 52-58.
12. Zyss T., Rachel W., Datka W., Hese R.T., Gorczyca P., Szwajca K. et al. Obecne miejsce terapii elektrowstrząsowej. Część 2: Aspekt kliniczny. Przegląd Lekarski, 2015, 72(1).

13. Grochowski M. Gdy klozapina nie wystarcza. Postępy Psychiatrii $i$ Neurologii, 2005, 14: 343-352.

14. Alacam, Huseyin, et al. "miR-181b-5p, miR-195-5p and miR301a-3p arerelated with treatmentresistance in schizophrenia." Psychiatry Research, 2016, 245: 200-206.

15. Barretto P., Kayo E. M., Avrichir M., Sa B.S., Camargo A.R., Napolitano M.D., I. C. et al. A preliminarycontrolledtrial of cognitivebehavioraltherapy in clozapine-resistantschizophrenia. The Journal of nervous and mentaldisease, 2009, 197(11), 865-868.

16. Kołodziej- Kowalska E., Rabe- Jabłońska J. Leczenie schizofrenii elektrowstrząsami oraz lekami przeciwpsychotycznymi, łącznie z elektrowstrząsami. Psychiatria i Psychologia Kliniczna, 2011, 11(4), 238-242.

17. Kupchik M., Spivak B., Mester R., Reznik I., Gonen N., Weizman A. et al. Combinedelectroconvulsive-clozapinetherapy. Clinicalneuropharmacology, 2000, 23(1), 14-16.

18. Kho K.H., Blansjaar B.A., De Vries S., Babuskova D., Zwinderman A. H., Linszen, D. H. Electroconvulsivetherapy for the treatment of clozapinenonresponderssuffering from schizophrenia. Europeanarchives of psychiatry and clinicalneuroscience, 2004, 254(6), 372-379.

19. Raffard S., Bortolon C., Macgregor A., Norton J., Boulenger J. P., El Haj, M. et al. Cognitiveinsight in schizophreniapatients and theirbiologicalparents: A pilot study. Schizophreniaresearch, 2016, 159(2), 471-477.

20. Asarnow R.F., Nuechterlein K.H., Fogelson D., Subotnik K.L., Payne D.A., Russell A.T. et al. Schizophrenia and schizophreniaspectrum personalitydisorders in the first-degreerelatives of children with schizophrenia: the UCLA family study. Archives of General Psychiatry, 2001, 58(6), 581-588.

\author{
Correspondence address \\ Ewelina Soroka \\ II Klinika Psychiatrii i Rehabilitacji Psychiatrycznej \\ Ul. Głuska 1, 20-439 Lublin \\ Email: dziwota.e@gmail.com
}

Otrzymano:02.09.2016

Zrecenzowano:17.09.2016, 10.10.2016,

02.11.2016,12.12.2016,14.12.2016

Przyjęto do druku: 22.12.2017 